\title{
Computational Docking Studies of Non-Structural Protein 2 Protease of Chikungunya with Phytochemicals
}

\section{Danish I Jasnaik* and Basilin Benson}

D Y Patil University, School of Biotechnology and Bioinformatics, CBD Belapur, Navi Mumbai, India

*Corresponding Author: Danish I Jasnaik, D Y Patil University, School of Biotechnology and Bioinformatics, CBD Belapur, Navi Mumbai, India.
Received: April 20, 2020

Published: May 18, 2020

(C) All rights are reserved by Danish I Jasnaik and Basilin Benson.

\section{Abstract}

Chikungunya virus (CHIKV) is a deadly Arbovirus that is transmitted to humans by the mosquito species Aedes aegypti. Infection is often associated with fever, headache, muscle pain, joint swelling, or rash. In the present study, the identification of selective inhibitors against Chikungunya virus is reported. The compounds considered were found to be inhibitors of DENGUE virus. The compounds were screened and their inhibitory activity was investigated using in-silico molecular docking study. Overall a total of 13 compounds were studied using molecular docking approach. The in-silico study of such selective inhibitors will contribute to a better understanding of the CHIKV replication cycle and also represent a step towards the development of a clinical candidate drug for the treatment of this disease.

Keywords: CHIKV; Molecular Docking; Phytochemicals

\section{Introduction}

Chikungunya virus (CHIKV) is an emerging arthrogenic arbovirus that belongs to the Alphavirus genus, family Togaviridae. It has been responsible for major outbreaks of devastating human arthritis disease during the past five years. Chikungunya fever caused by the virus was first described in 1952, after an outbreak on the Makonde Plateau (named after an ethnic group from East Africa), along the border between Tanganyika and Mozambique. After the 1973 outbreak in India, only sporadic activities were detected for the next 30 years, with no major recurrence until a large outbreak in Kenya in 2004. This initiated a spreading epidemic that reached numerous islands of the Indian Ocean, India, and parts of Southeast Asia, and was further detected in 18 countries throughout Asia, Europe, and North America via imported infectious carriers. The CHIKV mortality rate has been estimated to be 1:1000 and most of the deaths occur in neonates, adults with underlying conditions and the elderly [1]. Clinically approved drugs such as chloroquine, alpha-interferon and ribavirin showed some antiviral effect in vitro but did not prove to be effective against CHIKV infection in vivo [2]. In the last few years, an increasing number of research groups have focused their attention in identify novel anti-CHKV compounds. As a result, different natural products such as terpenoid compounds, phenothiazine compounds, have shown to impair CHIKV replication in cell-based systems. Despite all these, neither a selective antiviral drug nor a vaccine has been approved till date. CHIKV is an enveloped virus with an $11.8 \mathrm{~kb}$ single-stranded positive-sense RNA genome. It contains two open reading frames and encodes four non-structural proteins (nsP1, nsP2, nsP3, nsP4), three structural proteins (capsid, E1, E2) and two small polypeptides (E3, 6K) [3]. The four non-structural proteins possess enzymatic properties that are essential for virus replication and therefore are interesting targets for the identification of selective antiviral inhibitors. Among them, nsP2 protein plays an important role, its proteolytic activity is required to cleave the non-structural poly-protein protein into separate non-structural proteins. The present study aims to use $\mathrm{nsP} 2$ as a target for the development of selective phytochemicals as inhibitors of CHIKV replication. The main theme of this study was to target the hydrophobic pockets of CHIKV virus nsP2 to screen existing phytochemicals used as anti-dengue agents that could help in inhibition of the CHIKV infection.

\section{Materials and Methods}

In this study existing phytochemicals used as anti-dengue agents have been docked against CHIKV virus nsP2 protease to hypothesis that the anti-viral activity of the same phytochemicals can also be useful against CHIKV. Docking was carried out using AutoDock Vina [4].

\section{Refinement of receptor protein}

Three-dimensional (3D) structure of the Chikungunya virus nsP2 protease was retrieved from the Protein Data Bank (PDB) using PDB ID:3TRK (http://www.rcsb.org/pdb) [5]. The structure was Energy minimized using Swiss-PdbViewer [6]. This minimized structure was used as receptor for docking studies. 
Active site prediction

The active site residues of the Chikungunya virus nsP 2 protease, is predicted using Cast-P sever (Computer Atlas of Surface Topology of Proteins) [7].

\section{Ligand selection}

A literature survey was performed to find existing phytochemicals, which were found to be effective against viral diseases specially against Dengue Virus so as to check and hypothesis their anti-viral activity against Chikungunya virus. Chemical Structures of the phytochemicals were downloaded from PubChem database [8]. All these selected compounds were taken into consideration for molecular interaction study against the CHIKV nsP2 protease in the current study.

\section{Molecular docking}

The number of H-bond acceptors, H-bond donors, $\log \mathrm{P}$ and Molecular weight were obtained from Pubchem database [8]. Molecular docking was carried out using Auto Dock Tool from Scripts Vina Research Institute. Docking was used to predict both ligand orientation and binding affinity. The preferred orientation of Ligand to the receptor, when bound to each other to form a stable complex in three dimensional spaces is predicted. Auto Dock is a suite of automated docking tools. It is designed to predict how small molecules, such as substrates or drug candidates, bind to a receptor of known 3D structure. Auto Dock Vina [4] is a new generation of docking software from the Molecular Graphics Lab.

\section{Results}

The Three-dimensional (3D) structure of the Chikungunya virus nsP2 protease was retrieved from Protein Data Bank (PDB). The PDB ID was 3TRK (http://www.rcsb.org/pdb), which had resolution of $2.40 \AA$. All available phytochemicals were docked with the Chikungunya virus nsP2 Protease. AutoDock Vina provided 9 conformation for each phytochemicals Ligand-protein interaction for their binding affinity was carried out using AutoDock Vina 4.2.1 [4]. The lowest binding energy conformation in all clusters was considered as the most favorable docking pose. Chemical structures of selected phytochemicals have shown in figure 1. AutoDock Vina provided 9 conformation for each phytochemical. Carica papaya (Papain) ranked top from others. Physiochemical properties of the selected ligands are shown in table 1. Plant names from which compounds were derived, and detail about the interacting residues in the protein-ligand complex are shown in table 2 . Binding mode of ligands with receptor is shown in figure 2 .

\section{Discussion}

Chikungunya is an appalling disease and requires urgent attention to develop new inhibitory compounds that could work against it. The genome of chikungunya is a positive sense, single stranded RNA of about $11.8 \mathrm{~Kb}$ in size. It consists of two open reading frames (ORFs) one in the $5^{\prime}$ end encoding the non-structural protein precursors and other in the 3 ' end encoding the structural proteins.

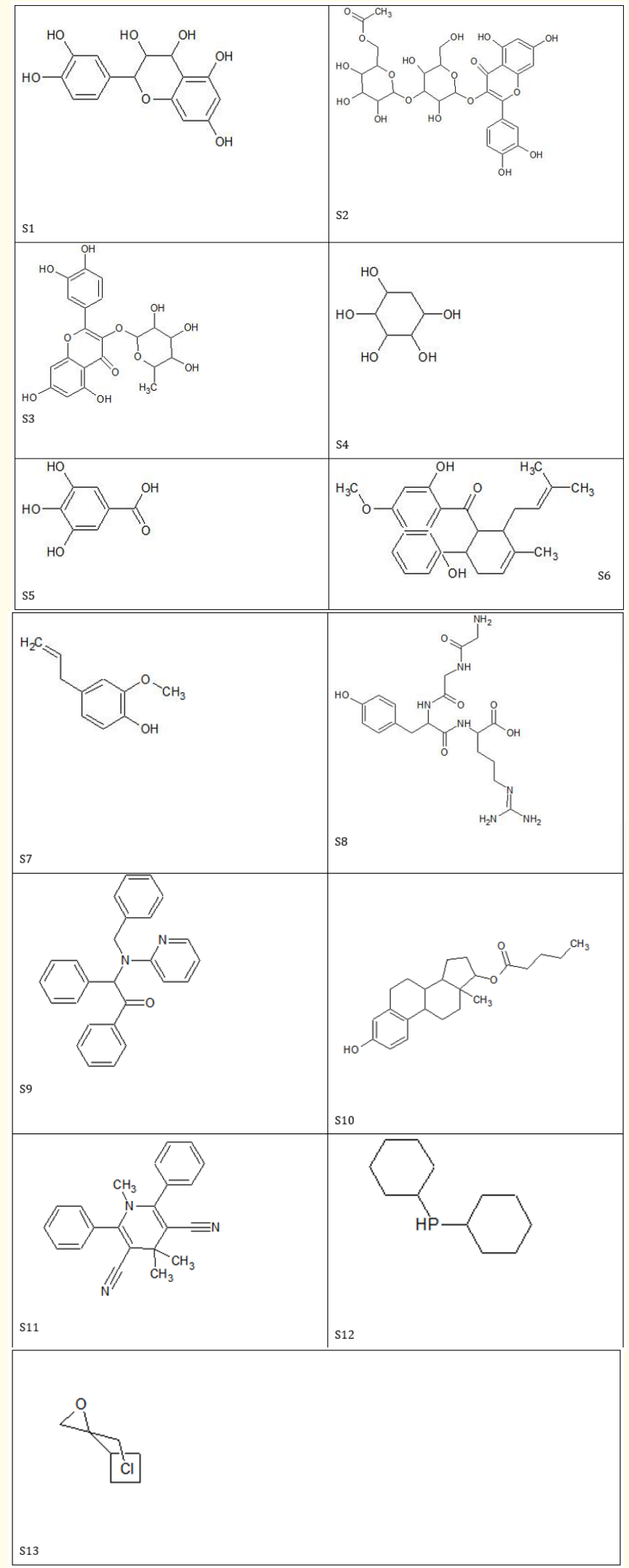

Figure 1: Chemical structures of selected phytochemicals

The cleavage of polyprotein is required for the replication of the virus which is carried out by non-structural protein 2 protease of CHIKV but any inhibitor against the nsp2 protease could stop the functioning of the protein thus leading to stop of cleavage. In 


\begin{tabular}{|c|c|c|c|c|}
\hline Phytochemical Compounds & XLogP3 & Molecular weight $\mathrm{g} / \mathrm{mol}$ & H Bond acceptor & H Bond donor \\
\hline $\begin{array}{l}(2 \mathrm{R}, 3 \mathrm{~S}, 4 \mathrm{~S})-2-(3,4 \text {-dihydroxyphenyl)-3,4-dihydro-2H- } \\
\text { chromene-3,4,5,7-tetrol }\end{array}$ & -0.8 & 306.26746 & 7 & 6 \\
\hline $\begin{array}{l}\text { [(3S,4S,6S)-6-[(2S,4S,5S)-2-[2-(3,4-dihydroxyphenyl)- } \\
\text { 5,7-dihydroxy-4-oxochromen-3-yl] oxy-3,5-dihydroxy- } \\
\text { 6-(hydroxymethyl)oxan-4-yl] oxy-3,4,5-trihydroxyoxan- } \\
\text { 2-yl]methyl acetate }\end{array}$ & -1.2 & 668.55358 & 18 & 10 \\
\hline $\begin{array}{l}\text { 2-(3,4-dihydroxyphenyl)-5,7-dihydroxy- } \\
\text { 3-[(2S,3R,4R,5R,6S)-3,4,5-trihydroxy-6-methyloxan- } \\
\text { 2-yl]oxychromen-4-one }\end{array}$ & 0.9 & 448.3769 & 11 & 7 \\
\hline (1R,2S,4S,5R)-cyclohexane-1,2,3,4,5-pentol & -2.7 & 164.15648 & 5 & 5 \\
\hline 3,4,5-trihydroxybenzoic acid & -- & 170.11954 & 5 & 4 \\
\hline $\begin{array}{l}\text { (2,6-dihydroxy-4-methoxyphenyl)-[(1R,2S,6R)-3-meth- } \\
\text { yl-2-(3-methylbut-2-enyl)-6-phenylcyclohex-3-en-1-yl] } \\
\text { methanone }\end{array}$ & 6 & 406.514 & 4 & 2 \\
\hline 2-methoxy-4-prop-2-enylphenol & 2 & 164.20108 & 2 & 1 \\
\hline $\begin{array}{l}(2 \mathrm{~S})-2-[[(2 \mathrm{R})-2-[[2-[(2 \text {-aminoacetyl)amino }] \text { acetyl }] \\
\text { amino]-3-(4-hydroxyphenyl)propanoyl }] \text { amino }]-5- \\
\text { (diaminomethylideneamino)pentanoic acid }\end{array}$ & -- & 451.47686 & 8 & 8 \\
\hline 2-[benzyl(pyridin-2-yl)amino]-1,2-diphenylethanone & 5.9 & 378 & 2 & 0 \\
\hline $\begin{array}{l}\text { (3-hydroxy-13-methyl-6,7,8,9,11,12,14,15,16,17- } \\
\text { decahydrocyclopenta[a]phenanthren-17-yl) pentanoate }\end{array}$ & 6 & 356.49838 & 3 & 1 \\
\hline 1,4,4-trimethyl-2,6-diphenylpyridine-3,5-dicarbonitrile & 4.4 & 325.40636 & 3 & 0 \\
\hline Dicyclohexylphosphane & 3.5 & 198.284782 & 0 & 0 \\
\hline 2-(chloromethyl)-2-cyclobutyloxirane & 1.6 & 146.61464 & 1 & 0 \\
\hline
\end{tabular}

Table 1: Physiochemical properties of phytochemical compounds from PubChem Database.

\begin{tabular}{|c|c|c|c|}
\hline Plant Name & Extracts & Affinity & Interacting Residues \\
\hline Euphorbia hirta & $\begin{array}{c}\text { (2R,3S,4S)-2-(3,4-dihydroxyphenyl)-3,4-di- } \\
\text { hydro-2H-chromene-3,4,5,7-tetrol }\end{array}$ & -7.9 & TRP1084, SER1048, LEU1205, MSE1242 \\
\hline Euphorbia hirta & $\begin{array}{c}{[(3 S, 4 S, 6 S)-6-[(2 S, 4 S, 5 S)-2-[2-(3,4-} \\
\text { dihydroxyphenyl)-5,7-dihydroxy-4-oxochromen- } \\
\text { 3-yl] oxy-3,5-dihydroxy-6-(hydroxymethyl) } \\
\text { oxan-4-yl]oxy-3,4,5-trihydroxyoxan-2-yl]methyl } \\
\text { acetate }\end{array}$ & -8.1 & Not suitable (High molecular weight) \\
\hline Euphorbia hirta & $\begin{array}{l}\text { 2-(3,4-dihydroxyphenyl)-5,7-dihydroxy- } \\
\text { 3-[(2S,3R,4R,5R,6S)-3,4,5-trihydroxy-6-methy- } \\
\text { loxan-2-yl] oxychromen-4-one }\end{array}$ & -8.4 & TRP1084, TYR1079, SER1048 \\
\hline Euphorbia hirta & (1R,2S,4S,5R)-cyclohexane-1,2,3,4,5-pentol & -5.1 & $\begin{array}{l}\text { ASN1082, ALA1046, TYR1047, TRP1084, TYR1079, } \\
\text { LEU1205 }\end{array}$ \\
\hline Euphorbia hirta & 3,4,5-trihydroxybenzoic acid & -5.5 & ASN1082, TRY1079, TRP1084, TYR1047 \\
\hline $\begin{array}{l}\text { Boesenbergia } \\
\text { rotunda }\end{array}$ & $\begin{array}{l}\text { (2,6-dihydroxy-4-methoxyphenyl)-[(1R,2S,6R)- } \\
\text { 3-methyl-2-(3-methylbut-2-enyl)-6-phenylcyclo- } \\
\text { hex-3-en-1-yl]methanone }\end{array}$ & -7.8 & TYR1079, TRP1084, MSE1242, GLN1241 \\
\hline $\begin{array}{l}\text { Ocimum sanc- } \\
\text { tum }\end{array}$ & 2-methoxy-4-prop-2-enylphenol & -4.8 & TYR1079, TRP1084, MSE1242 \\
\hline Carica papaya & $\begin{array}{c}(2 \mathrm{~S})-2-[[(2 \mathrm{R})-2-[[2-[(2 \text {-aminoacetyl)amino }] \\
\text { acetyl]amino]-3-(4-hydroxyphenyl)propanoyl] } \\
\text { amino]-5-(diaminomethylideneamino)penta- } \\
\text { noic acid }\end{array}$ & -9.6 & ASN1082, ALA1046, TRP1084, SER1048, MSE1242 \\
\hline Mappia foetida & $\begin{array}{c}\text { 2-[benzyl(pyridin-2-yl)amino]-1,2-diphenyle- } \\
\text { thanone }\end{array}$ & -9.1 & TYR1079, GLN1241, MSE1242 \\
\hline
\end{tabular}




\begin{tabular}{|c|c|c|c|}
\hline Mappia foetida & $\begin{array}{c}\text { (3-hydroxy-13-methyl-6,7,8,9,11,12,14,15,16,17- } \\
\text { decahydrocyclopenta[a]phenanthren-17-yl) } \\
\text { pentanoate }\end{array}$ & -7.5 & $\begin{array}{c}\text { MSE1242, LEU1243, LEU1203, LYS1239, ILE1221, } \\
\text { GLU1204, PRO1191 }\end{array}$ \\
\hline Mappia foetida & $\begin{array}{c}\text { 1,4,4-trimethyl-2,6-diphenylpyridine-3,5-dicar- } \\
\text { bonitrile }\end{array}$ & -6.8 & PR01191, GLY1176, TYR1177, HIS1222, ILE1221 \\
\hline Mappia foetida & $\begin{array}{c}\text { Dicyclohexylphosphane } \\
\text { Mappia foetida }\end{array}$ & -6.3 & $\begin{array}{c}\text { LEU1243, GLU1204, LYS1045, MSE1238, ALA1046, } \\
\text { LYS1239, TYR1047 }\end{array}$ \\
\hline 2-(chloromethyl)-2-cyclobutyloxirane & -4.9 & MSE1242, MSE1238, LYS1045, LYS1239 \\
\hline
\end{tabular}

Table 2: Plant names from which phytochemicals have been derived and information about interacting residues.

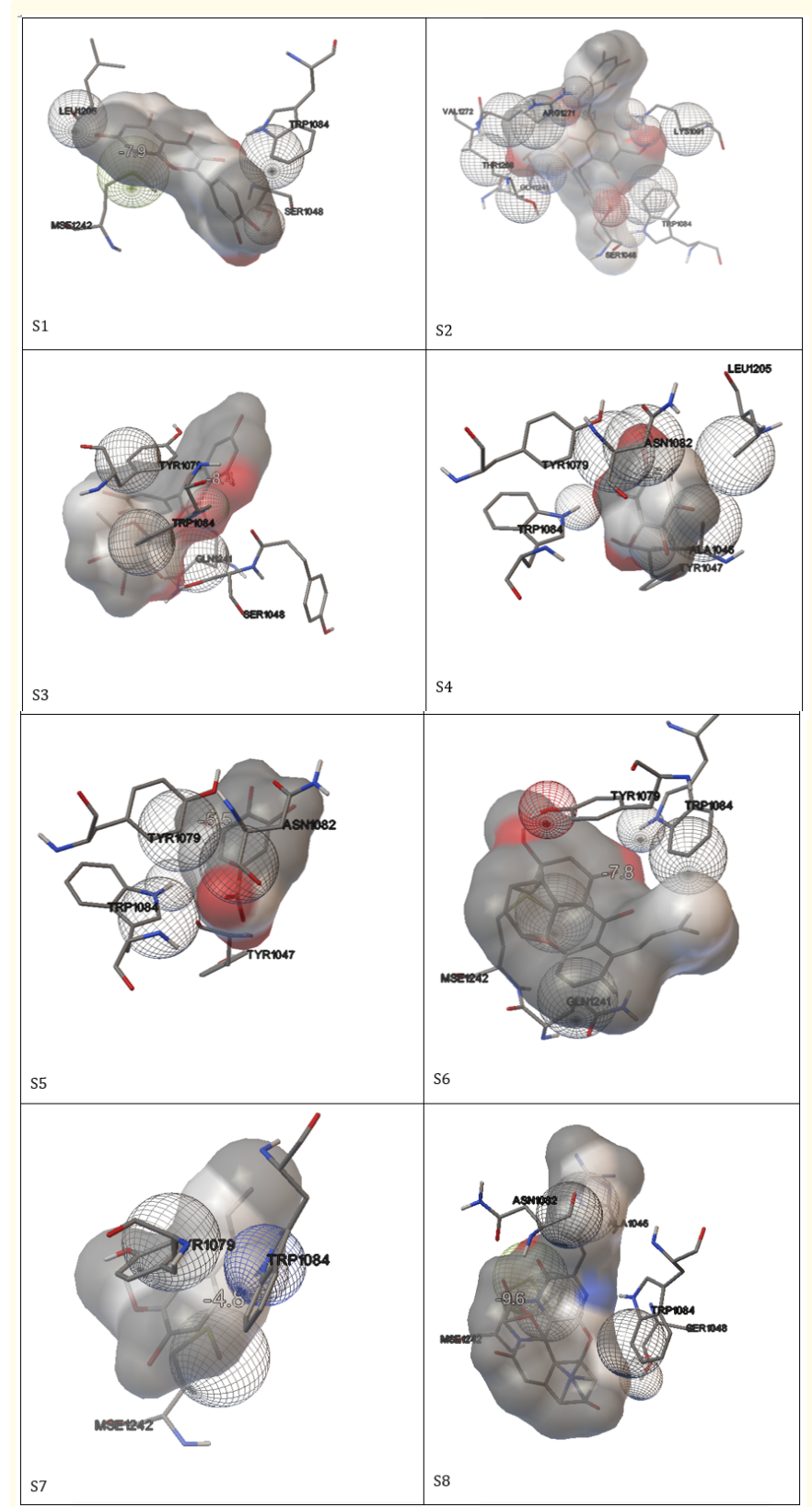

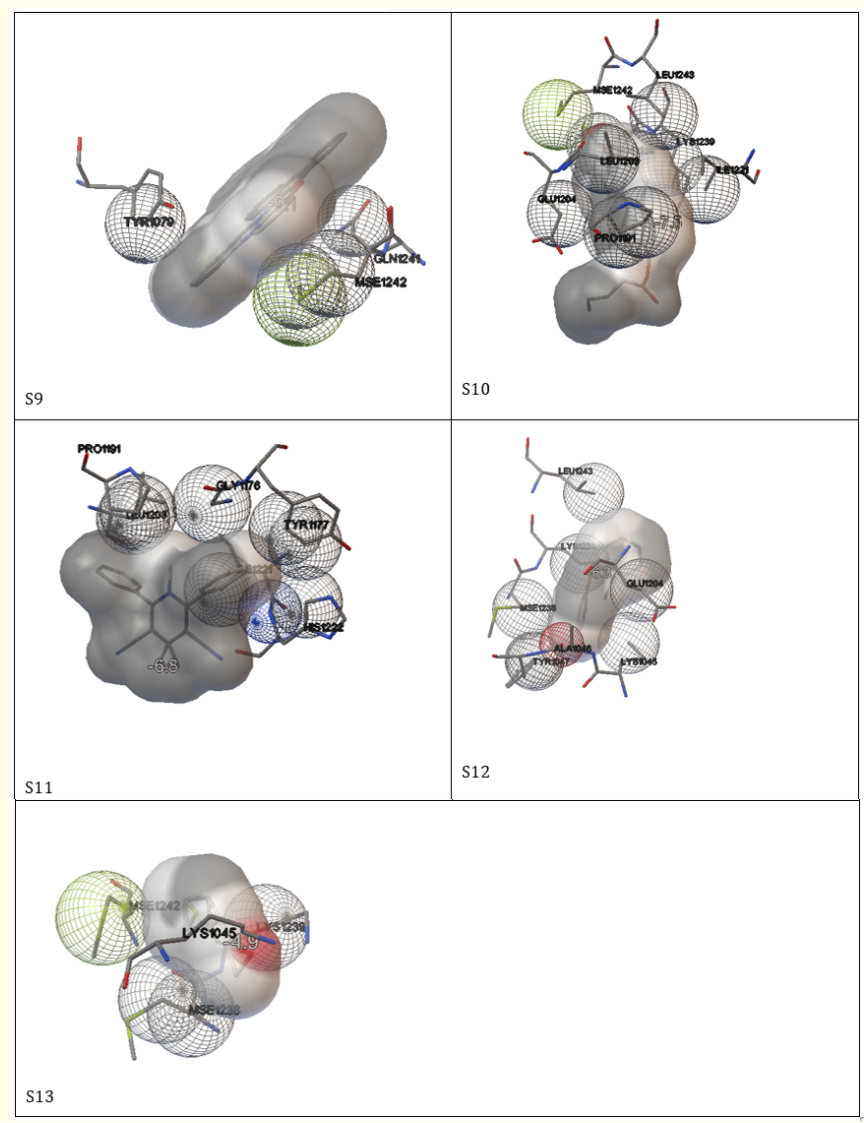

Figure 2: Binding interactions of ligands with nsp2 protease.

recent research, computational techniques have been used to estimate the binding affinity of different existing phytochemicals to inhibit this cleavage of polyprotein carried out by non-structural protein 2 protease of CHIKV in order to inhibit the replication process of the virus. The current is study focused on the docking of the plant's phytochemicals against nsp2 protease. The potential of 8 phytochemicals were examined against Chikungunya virus nsp2 protease. Alkaloids were downloaded from different databases. In this study, 13 phytochemicals were docked with the Chikungunya virus nsp 2 protease to find their affinity as inhibitors. Only top conformations after docking was selected based on minimum affinity score. This study has discovered potential binding of phytochemicals from plants Euphorbia hirta, Carica papaya [9-13]. 


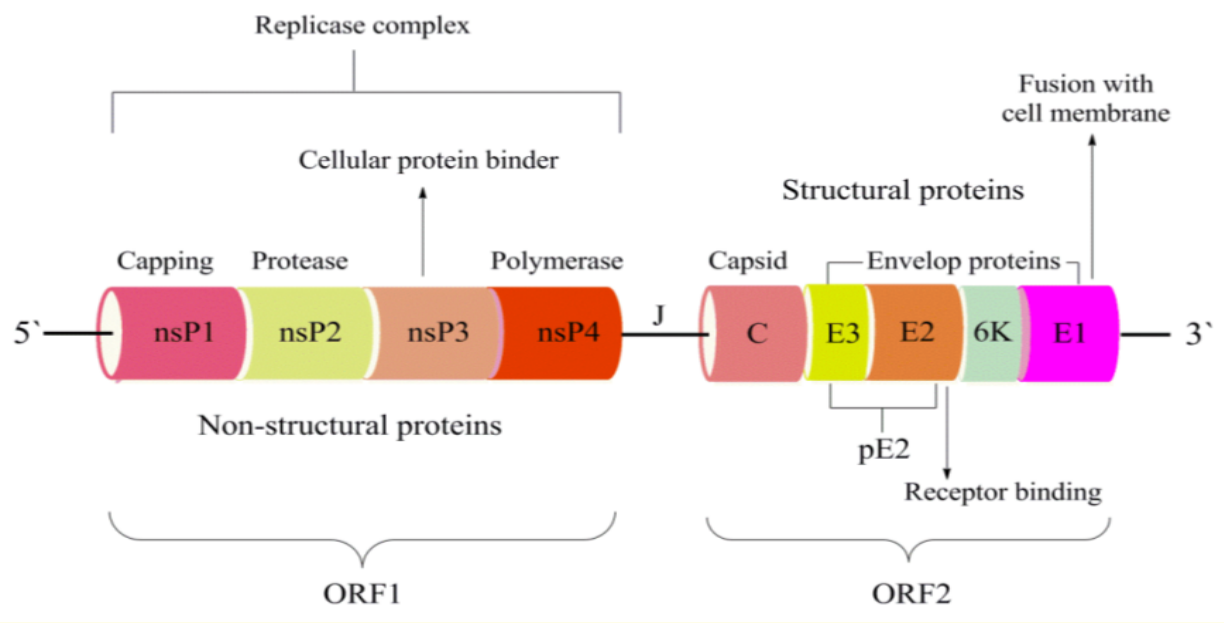

Figure 2: Schematic representation for the CHIKV genome [1].

\section{Conclusion}

The work presented in this study underlines the usefulness of using in-silico methodology that is useful in the identification for selective antiviral compounds for chikungunya. In this case, by using virtual screening and molecular docking studies, we identified selective inhibitors of nonstructural protein protease 2 of chikungunya virus. In particular, compound S8 has a very promising activity as an inhibitor of chikungunya. It is important to underline that despite the results of the molecular docking studies, further experimental studies are required to prove that these compounds are indeed nsP2 inhibitors. However, notwithstanding the mode of action of these inhibitors, the promising results reported here could represent an initial step towards the discovery of a clinical candidate for the treatment of CHKV infections.

\section{Bibliography}

1. Adel Rashad., et al. "Chikungunya virus: emerging targets and new opportunities for medicinal chemistry". Journal of Medicinal Chemistry 57.4 (2014): 1147-1166.

2. De Lamballerie X., et al. "On chikungunya acute infection and chloroquine 329 treatment". Vector-Borne and Zoonotic Diseases 8.6 (2008): 837-839.

3. Strauss JH and Strauss EG. "The alphaviruses: gene expression, replication, and 372 evolution". Microbiology Reviews 58.3 (1994): 491-562.

4. Trott $\mathrm{O}$ and Olson AJ. "AutoDockVina: improving the speed and accuracy of docking with a new scoring function, efficient optimization and multithreading". Journal of Computational Chemistry 31.2 (2010): 455-461.
5. Helen M Berman., et al. "The Protein Data Bank". Nucleic Acid Research 28.1 (2000): 235-242.

6. Guex N and Peitsch MC. "SWISS-MODEL and the Swiss-PdbViewer: An environment for comparative protein modeling". Electrophoresis 18.15 (1997): 2714-2723.

7. Dundas J., et al. "CASTp: computed atlas of surface topography of proteins with structural and topographical mapping of functionally annotated residues". Nucleic Acid Research 34 (2006): W116-W118.

8. Bolton E., et al. "PubChem: Integrated Platform of Small Molecules and Biological Activities". Chapter 12 IN Annual Reports in Computational Chemistry 4 American Chemical Society, Washington, DC (2008): 217-241.

9. Asthma Weed Tea (infusio Euphorbia hirta) from Amazon Herbs .

10. Rothan., et al. "Inhibition of dengue NS2B-NS3 protease and viral replication in Vero cells by recombinant retrocyclin-1". BMC Infectious Diseases 12 (2012): 314.

11. Barbosa JD., et al. "Structure-activity relationships of eugenol derivatives against Aedes aegypti". Pest Management Science 68.11 (2012): 1478-1483.

12. Papaya Leaf Relief for Chikungunya Virus (2013).

13. M Ramalingam., et al. "Docking Studies of HIV-1 Protease with Phytochemicals from Mappia foetida". International Journal of Computer Applications 43.4 (2012). 
Assets from publication with us

- Prompt Acknowledgement after receiving the article

- Thorough Double blinded peer review

- Rapid Publication

- Issue of Publication Certificate

- High visibility of your Published work

Website: https://www.actascientific.com/

Submit Article: https://www.actascientific.com/submission.php

Email us: editor@actascientific.com

Contact us: +919182824667

Citation: Danish I Jasnaik and Basilin Benson. "Computational Docking Studies of Non-Structural Protein 2 Protease of Chikungunya with

Phytochemicals". Acta Scientific Microbiology 3.6 (2020): 80-85. 